\title{
Response to comment on: Haider DG, Schaller G, Kapiotis S, Maier C, Luger A, Wolzt $M$ (2006) The release of the adipocytokine visfatin is regulated by glucose and insulin. Diabetologia 49:1909-1914
}

\author{
D. G. Haider • M. Wolzt
}

Received: 17 July 2006 / Accepted: 24 July 2006 / Published online: 22 September 2006

(C) Springer-Verlag 2006

\section{To the Editor:}

We read with interest the comments by Pfützner and Forst [1] on our recent article in Diabetologia [2]. Circulating visfatin concentrations in healthy young subjects are generally lower than those in patients with diabetes or elderly subjects at risk. As there is only one CE-marked ELISA test kit commercially available at the moment (Phoenix Peptides, Karlsruhe, Germany), one would anticipate that data generated should be comparable among reports. However, authors have demonstrated considerable variation in visfatin serum/plasma concentrations. In our experience, circulating visfatin ranges from as low as $0.4 \mathrm{ng} / \mathrm{ml}$ in healthy children [3] to $92.3 \mathrm{ng} / \mathrm{ml}$ [4] in patients with type 1 diabetes. This range is consistent with data presented by other researchers in patients with type 2 diabetes (range $2-50 \mathrm{ng} / \mathrm{ml}$ ) $[5,6]$ or gestational diabetes (range $5-90 \mathrm{ng} / \mathrm{ml}$ ) [7, 8]. Importantly, serum/plasma visfatin was not different in fresh samples from healthy young volunteers compared with specimens stored at $-30^{\circ} \mathrm{C}$. The slow decomposition of visfatin is therefore unlikely to account for differences between groups of healthy subjects when freezing conditions are maintained. However, we agree with the comment that the considerable range of circulating visfatin is a limiting factor in many studies and should prompt investigators to treat these results with caution, particularly when cross-sectional studies are being analysed. A systematic error introduced by an analytical method may still reflect changes over time in acute

D. G. Haider $\cdot$ M. Wolzt $(\bowtie)$

Department of Clinical Pharmacology,

Medical University of Vienna,

Währinger Gürtel 18-20,

A-1090 Vienna, Austria

e-mail: michael.wolzt@meduniwien.ac.at interventional studies, i.e. increased systemic visfatin concentrations, even if the amplitude is attenuated or augmented. Finally, only endogenous insulin concentrations during glucose infusion are given in the manuscript to avoid duplicate publication; the reader is referred to a previous publication where more detailed insulin concentrations are presented [9].

\section{References}

1. Pfützner A, Forst T (2006) Comment on: Haider DG, Schaller G, Kapiotis S, Maier C, Luger A, Wolzt M (2006) The release of the adipocytokine visfatin is regulated by glucose and insulin. Diabetologia 49:1909-1914. DOI 10.1007/s00125-006-0391-4

2. Haider DG, Schaller G, Kapiotis S, Maier C, Luger A, Wolzt M (2006) The release of the adipocytokine visfatin is regulated by glucose and insulin. Diabetologia 49:1909-1914

3. Haider DG, Holzer G, Schaller G, Weghuber D, Widhalm K, Wagner $\mathrm{O}$ et al (2006) The adipokine visfatin is markedly elevated in obese children. J Pediatr Gastroenterol Nutr (in press)

4. Haider DG, Pleiner J, Francesconi M, Wiesinger GF, Muller M, Wolzt M (2006) Exercise training lowers plasma visfatin concentrations in patients with type 1 diabetes. J Clin Endocrinol Metab. DOI 10.1210/jc.2006-1013

5. Berndt J, Kloting N, Kralisch $\mathrm{S}$ et al (2005) Plasma visfatin concentrations and fat depot-specific mRNA expression in humans. Diabetes 54:2911-2916

6. Hammarstedt A, Pihlajamäki J, Rotter Sopasakis V et al (2006) Visfatin is an adipokine, but it is not regulated by thiazolidinediones. J Clin Endocrinol Metab 91:1181-1184

7. Krzyzanowska K, Krugluger W, Mittermayer F et al (2006) Increased visfatin concentrations in women with gestational diabetes mellitus. Clin Sci (Lond) 110:605-609

8. Chan TF, Chen YL, Lee CH et al (2006) Decreased plasma visfatin concentrations in women with gestational diabetes mellitus. J Soc Gynecol Investig 13:364-367

9. Schaller G, Schmidt A, Pleiner J, Woloszczuk W, Wolzt M, Luger A (2003) Plasma ghrelin concentrations are not regulated by glucose or insulin: a double-blind, placebo-controlled crossover clamp study. Diabetes 52:16-20 